\title{
Teoreettinen näkökulma verkkovihaan
}

\author{
Ari Haasio \\ Seinäjoen ammattikorkeakoulu \\ ari.haasio@seamk.fi
}

Keipi, M., Näsi, M., Oksanen, A. \& Räsänen, P. 2017. Online Hate and Harmful Content: Cross-national perspectives. Abingdon, New York: Routledge.

Asiasanat: Internet; vihapuhe; sosiaalinen media; nuoret; informaatio

Vihapuhe ja valemedia ovat 2010-luvun viestinnän keskeisiä kysymyksiä. Ilmiöinä ne eivät ole uusia, mutta nykyisessä maailmanpoliittisessa tilanteessa ne ovat valitettavan ajankohtaisia. Informaatiotutkimuksen kannalta vihapuheeseen ja valemediaan keskeisesti liittyvä disinformaation ja misinformaation problematiikka tekee ilmiön kiinnostavaksi paitsi yhteiskunnallisesti, myös epistemologisesti.

Online Hate and Harmful Content: Cross-national perspectives -teoksen kirjoittajat ovat kokeneita suomalaisia tutkijoita ja kirjaan on saatu poikkitieteellinen näkökulma kirjoittajien erilaisten osaamisalueiden ansiosta. Professori Pekka Räsänen on tutkinut muun muassa kuluttajakäyttäytymistä, sosiaalista epätasa-arvoa ja väkivaltaa, ja professori Atte Oksanen on käsitellyt aiemmissa tutkimuksissaan muun muassa kriminologiaa ja nuorisotutkimusta. YTT Matti Näsi puolestaan on perehtynyt informaation ja kommunikaation sekä yhteiskunnan ja sosiaalisen elämän välisiin vuorovaikutussuhteisiin, ja YTT Teo Keipi on tutkinut anonymiteettia, identiteettiä ja tietoverkon vaikutusta erityisesti nuoriin. 
Keipin ja kumppaneiden teoksen eräs merkittävimmistä ja näköaloja avaavimmista seikoista on tutkimuskysymyksen tarkastelu usean eri valtion näkökulmasta. Kirja tarjoaa tilastotietoa ja analysoi teemaa niin Suomen, Yhdysvaltain, Britannian kuin Saksan osalta. Näin kuva vihapuheesta ja haitallisista verkkosisällöistä eri maiden välisine yhtäläisyyksineen ja eroineen tuo ilmiöön uutta ulottuvuutta.

Vaikka vihapuhe, petokset, kiusaaminen ja muut internetin lieveilmiöt ovat kaikkien verkon käyttäjien ongelmia, kirjan fokus on nuorten ja nuorten aikuisten kohtaamissa ongelmissa. Teoksen painotus on verkkovihan käsittelyssä erityisesti sosiaalisen median näkökulmasta. Valemedia on nykyisin kasvava uhka totuudenmukaiselle tiedonvälitykselle ja se välittää usein vihapuhetta ja ruokkii rasismia. Erityisesti vihapuhe on teema, joka koskettaa hyvin voimakkaasti kaikenikäistä väestöä. Kotimaisessa valemediassa keski-ikäiset kansalaiset ovat hyvin aktiivisia ja tuottavat vihapuhetta runsaasti. Valemediaa ja sen merkitystä ennen muuta vihapuheen lietsojana ei teoksessa ole mielestäni huomioitu tarpeeksi laajalti.

Verkkoyhteisöt rakentuvat kirjoittajien mukaan neljän keskeisen elementin varaan, jotka ovat informaatio, anonymiteetti, sosiaaliset verkostot ja viihde. Kolme ensin mainittua tarjoavat kirjottajien mukaan selityksen sille, miksi verkkovihan näkyvyys ja vaikutus ovat tänä päivänä niin merkittäviä. Näistä anonymiteetti lienee kuitenkin se, joka mahdollistaa sopimattoman käyttäytymisen. Mistä viha sinänsä johtuu on eri asia - verkon anonymiteetti luo sille mahdollisuuden kukoistaa. Mielenkiintoista on, että vertailtaessa verkkovihan eri muotoja Suomessa, Saksassa, Yhdysvalloissa ja Britanniassa, ne saavat erilaisia muotoja ja se, mihin verkkoviha kohdistuu eri maissa, vaihtelee maittain. Esimerkiksi Suomessa sukupuoleen kohdistuvaa verkkovihaa on näistä maista vähiten, kun taas seksuaalisen suuntautumisen ja etnisyyden teemat ovat tarkastelluista maista meillä eniten vihamainintoja saaneita. Teos avaakin mielenkiintoisen näkökulman verkkovihaan: eri maissa se kohdistuu maan kulttuurista ja historiasta johtuen eri asioihin.

Kirjoittajat nostavat hyvin esiin "suodatinkuplan" kääntöpuolet. Kun Google ja useat muut palvelut tarjoavat uusia sivuja ja palveluja, joista saattaisit hakuhistoriasi tai muun verkkokäyttäytymisesi perusteella pitää, ruokkii tämä "suodatinkupla" heidän mukaansa myös negatiivista käyttäytymistä. Vierailemalla viha-, porno- tai väkivaltasivuille käyttäjä saa uusia ehdotuksia vastaavista sivustoista. Tämä on varmasti totta. "Suodatinkupla" aiheuttaa maailmankuvan kaventumisen ja vaihtoehtoisen informaation poissulkemisen hyvin helposti ja saattaa näin vahvistaa negatiivisia käyttäytymismalleja verkossa.

Vihapuheesta ja verkon pimeästä puolesta puhuttaessa huomio kiinnittyy useimmiten verkkorikollisiin, vihapuheeseen syyllistyviin henkilöihin ja muihin toimijoihin, jotka käyttäytyvät vastoin verkon normeja. Keipi ja kumppanit pohtivat asiaa myös uhrin kannalta teoreettisella tasolla ja päätyvät siihen kiintoisaan lopputulokseen, että elämäntapa ja rutiinit ovat tähän vaikuttavia tekijöitä. Tämän johto- 
päätöksen taustalla on kaksi teoriaa: Lifestyle Exposure Theory (LET) ja Routine Activity Theory (RAT). Elämäntavan ja tiedonhankinnan keskinäisvaikutusta on pohdittu runsaasti informaatiotutkimuksen saralla ja kirjoittajien osoittama LET ja RAT-teorioiden vaikutus uhriksi joutumiseen ja miksei myös tekijäksi ryhtymiseen on kiinnostava. Tätä jaottelua voisikin soveltaa nähdäkseni myös silloin, kun tutkitaan verkkoriippuvuutta tai verkon käytön kulttuurisia piirteitä laajemminkin. Nämä teemat avaavat myös informaatiotutkimuksen saralla useita kiintoisia tutkimuskohteita.

Yhtenä kirjan keskeisenä antina tekijät esittelevät IBR-mallin (Identity Bubble Reinforcement), jonka avulla he selittävät riskikäyttäytymistä ja sitä vahvistavia tekijöitä. Mallin taustalla on ajatus siitä, että sosiaalisessa mediassa jaamme asioita ystävillemme jotka ovat saman mielisiä ja kuulumme esimerkiksi ryhmiin, joiden arvot ovat yhteneviä kanssamme. Näin sieltä saatu palaute vahvistaa ajatuksiamme, myös silloin on kyse vihasta, rasistisista näkemyksistä tai muista negatiivisista tunteen tai mielipiteiden ilmauksista. Kirjoittajien esittämä malli on oivaltava. Se on tavallaan käänteistä parviälyä: kun jaamme tietoa, se kumuloituu ja kun jaamme negatiivisia ilmauksia ne kumuloituvat ja ruokkivat meitä ajattelemaan entistä negatiivisemmin ja rohkaisevat vihapuheeseen ja muihin vastaaviin tekoihin verkossa.

Eräänä IBR-mallin taustavaikuttimena voidaan nähdä Sosiaalisen identiteetin teoria (SIT = Social Identity Theory), jonka mukaan sosiaalinen identiteetti märittelee yksilölle kuka ja mitä hän on. Tätä sosiaalipsykologiassa käytettyä ajatusta Keipi ja kumppanit ovat soveltaneet teoksessaan nyt verkkoyhteisöihin.

Verkkovihan ja muiden verkon lieveilmiöiden teoreettiseen taustoitukseen Keipin ja kumppaneiden teos tuo tervetulleen lisän. Vaikkakin empiirisiä havaintoja ja esimerkkejä on neljästä maasta, olisi vertailtavia maita kuitenkin voinut olla enemmän. Laajempi vertailupohja olisi havainnollistanut teorioiden sovellusmahdollisuuksia paremmin.

Online Hate and Harmful Content on kirja, joka auttaa ymmärtämään teoreettisesti verkkovihaa sekä muuta verkossa tapahtuvaa ei-toivottavaa käyttäytymistä ja niitä mekanismeja, jotka ruokkivat ja ylläpitävät sitä. Kirjoittajien esittelemä IBRmalli on myös kiintoisa teoreettinen jäsennys, joka tarjoaa hyvän viitekehyksen vihapuheen ja sen retoriikan tutkimukselle. Erityisesti informaatiotutkimuksen näkökulmasta olisi mielenkiintoista etsiä vihapuheen diskursseja ja tutkia sitä vuorovaikutusta ja ryhmän yhteisen mielipiteen muodostamista IBR-malliin tukeutuen. Kirjaa voi pitää onnistuneena kokonaisuutena, joka luo hyvän teoreettisen näkökulman vihapuheeseen ja muihin verkon lieveilmiöihin. Näitä teemoja tutkivalle Keipin ja kumppaneiden teos avaa uusia näkökulmia eri ilmiöiden teoretisointiin. 